\title{
Application of structural equation modeling for assessing relationships between organic carbon and soil properties in semiarid Mediterranean region
}

\author{
${ }^{1 *}$ N. Brahim; ${ }^{2}$ D. Blavet; ${ }^{1}$ T. Gallali; ${ }^{2}$ M. Bernoux \\ ${ }^{1}$ U.R. 04/UR/10-02 Pedology, Department of Geology, Faculty of Sciences of Tunis, El Manar University, 2092 Tunis, \\ Tunisia \\ ${ }^{2}$ Research Institute for Development-IRD, UMR Eco and Soil,, Functional Ecology and Biogeochemistr of Soils and \\ Agro-Ecosystemsy, Bldg. 12, 2 place Viala, 34060 Montpellier Cedex 2, France \\ Received 21 June 2010; $\quad$ revised 11 September 2010; accepted 14 January 2011; $\quad$ available online 1 March 2011
}

\begin{abstract}
Restoration of atmospheric carbon in soils has principal many good effects. Arid lands cover more than $40 \%$ of the global earth area, but only stock $16 \%$ from the global carbon stock. It seems to be a suitable solution for this environmental issue, but still all variables controlling organic carbon in such kinds of soil, was ignored. This study aims to develop two models of organic carbon under clayey and sandy soils in semi-arid Mediterranean zones basing on physical and chemical soil properties. For establishing both models, structural equation modeling was used. For modeling organic carbon, two Tunisian soil databases composed from clayey and sandy soils made respectively, of 450 and 602 soil horizons were used. Using the two databases for all properties, the principal component analysis shows two components for clayey soil; (i) chemical properties and bulk density and (ii) physical properties. For the sandy soil it reveals two components; (i) chemical properties and (ii) physical properties. According to the derived components for each soil category, two models have been built. Structural equation modeling results show that clayey model has proved that organic carbon was controlled by chemical properties and bulk density more than physical properties and sandy model has proved that organic carbon was controlled by chemical properties more than physical properties. The root mean square errors of approximation were 0.079 and 0.050 for the clayey and sandy models, respectively. Then these two models were validated with two other databases from Tunisian dryland soils.
\end{abstract}

Keywords: Drylands; Linear causal modeling; Organic matter; Path analysis; Soil texture

\section{INTRODUCTION}

Soil is a significant terrestrial carbon (C) reservoir which plays a notable role in the global carbon cycle, it contains about $1500 \mathrm{Pg} \mathrm{C}\left(1 \mathrm{Pg}=10^{15} \mathrm{~g}=1\right.$ billion tons) in the surface meter of soil (Eswaran et al., 1995; Batjes, 1996; Batjes and Sombroek, 1997; Lal, 2002) and $684 \mathrm{Pg} \mathrm{C}$ in the upper 30cm layer (Batjes, 1996). Soils of drylands, of mainly arid and semi-arid tropical and mid-latitude regions of the world, contain about $251 \mathrm{Pg}$ C of soil organic carbon (SOC) in the upper 100 cm (Batjes, 1999). Soils represent key sources and important sinks of greenhouse gas $\mathrm{CO}_{2}$ and $\mathrm{CH}_{4}$, as well as main sources of $\mathrm{N}_{2} \mathrm{O}$ (Scholes and Andreae, 2000; Schuman et al., 2002). It is worth noting that the knowledge of the distribution of carbon sources and * *Corresponding Author Email: brahimnadhem@yahoo.fr Tel.: +216 99729 892; Fax: +216 71885408 sinks and their variation over time is vital for realizing the mechanisms controlling the global terrestrial carbon cycle and the sustainability of current carbon sinks (Chen et al., 2003; Goyal et al., 2008). Moreover, such knowledge is crucial for planning climate change policies. In fact, growth in decomposition of soil organic matter (OM), ensuing from global warming or from land use change (Houghton, 1991), could considerably enlarge the atmospheric burden of $\mathrm{CO}_{2}$, which would further improve the greenhouse effect. On the other hand, soils could also offer a reservoir for increased sequestration of atmospheric carbon under certain climatic and management regimes. SOC is a major determinant of soil fertility, productivity and it represents an excellent indicator of soil quality in semiarid zone where soils have a small external input 
(Zarnoza et al., 2007b; Okoye et al., 2010; Chen et al., 2010). Changes in organic carbon (OC) content of soils have been shown to correlate with changes in the structural form and stability of soils and the magnitude of the change in structural characteristics is often strongly dependent on soil structure (Kay, 1998; Bandyopadhyay and Chattopadhyay, 2007; Bicheldey and Latushkina, 2010). Three major factors controlling the growth of SOC levels as well as it is fall: (i) the first factor is climatic such as the temperature and the moisture conditions (Paustian et al., 1997; Schlesinger, 2000; Lal, 2002, 2003), (ii) the second one is biological as the residue input and the plant composition (Sanger et al., 1997; Quideau et al., 1998) and (iii) the third factor is physico-chemical for instance the soil structure and texture, the clay content and mineralogy, the acidity and the OM content were enumarated (Paustian et al., 1997). Generally, the soil organic matter (SOM) is controlled by these factors. Whereas, each climatic area is characterized by the domination of some factors. For example, in tropical and equatorial zones the vegetation and mineralogy are the most variable controlling the OM content (Bernoux et al., 2002). While, in semi-arid zones SOM is controlled by the physico-chemical soil factors regarding the little litter restitution and the higher temperature. It is worth noting that drylands have the potential to be sink of 1.0 Pg C/yover the next 50 years. Dryland restoration thus could have a main effect on global climates because the non-forested world's drylands is $5.2 \times 10^{9}$ ha, in other words $43 \%$ of the earth's surface (Batjes, 1999). About $29.7 \%$ of this area is located in the arid zones, $44.3 \%$ in semi-arid zones and $26 \%$ in subhumid zones. In Africa, which encloses $24.1 \%$ of the drylands, the lands that are situated in semi-arid and arid zones are vulnerable. At these zones, lands lose about 0.5 to $1 \%$ of their productivity, in other words they lose at least $20 \%$ of their productivity in the last 40 years. Several ecosystems in Mediterranean zone of Africa have been degraded due to soil erosion, augmented cultivation, forest clearance and loss of bio-diversity. The deforestation as well as the land degradation in semi-arid Mediterranean zone account for the release of more carbon to the atmosphere (Zornoza et al., 2007a). For example, the rigorously tilled soils of semi-arid Mediterranean areas are likely to become degraded by losing their organo-mineral particle size fractions (Zornoza et al., 2007b). In these soils characterized by little SOM content, the organo- mineral particle-size fractions must be considered of huge importance, both in amount as well as in their capacity as medium and long term reservoirs for organically bound plant nutrients (Christensen, 1986; Caravaca et al., 1999), by physically protecting some OM fractions (Hassink and Whitmore, 1997).

According to Christensen (1996) the fixation of SOC includes chemical stabilization, biochemical process, and physical protections. The nature of different organo-mineral associations and their distribution within soil aggregates determine the extent to which SOC is physically protected and chemically stabilized (Randall et al., 1995), ensuing in organic stocks with varying input and turnover rates. OM is principally responsible for macro-aggregate stability (Puget et al., 1995) and the SOC that is linked to macro-aggregates is less processed than that of micro-aggregates, as reflected by higher $\mathrm{C} / \mathrm{N}$ ratios of the former (GarciaOliva et al., 1999). In addition, SOC has a significant influence on the water infiltration and on the stabilization of the aggregate (Bell et al., 1999; Chenini and Khemiri, 2009). Therefore, physically protection of OM within aggregates comes from coarse textured soils which contain essentially the young litter. Koutika et al. (1999) note that SOC decomposition is lower in soils' upper horizon of fine texture than those of coarse texture. Fractions of clay and fine silt maintain the majority of OC (Feigl et al., 1995). Microbial activities in clay are more stable against mineralization induced by farming than plant residues sequestered in soils' coarse fractions (Guggenberger et al., 1995). Specific surface of clay minerals increase from kaolinite to illite, and from illite to vermiculite (Dixon, 1991; Abate and Masini, 2005; Suthar and Singh, 2008) and influences the ability of clays to absorb humic substances (Willms et al., 2004; Abate and Masini, 2005; Abdel-Ghani and Elchaghaby, 2007). The resistance of clay-organic matter complexes against microbial activity declines as follows allophane 2:1 clays to 1:1 clays (Sombroek et al., 1993). It is proved that OC content at allophane has a mean residence times comprised between 2000 to 5000 years (Wada and Aomine, 1973). And it is interesting to note that according to Torn et al. (1997) and Batjes (1999) the impact of mineralogy on SOC storage has the same importance as that attributed to vegetation or climate. Mineralogy in temperate and tropical soils is the principal factor influencing the OC turnover and in second position the chemical factors were found. However, little is known about SOC stocks 
in the Mediterranean semi-arid zone and some researchers are focused at the carbon emission and sequestration potentials in soils (Batjes, 2006; Henry et al., 2009), whereas fewest interested in relationship of carbon and other properties of soils.

In this study, a structural equation modeling (SEM) was introduced; this methodology has the flexibility to (i) translate fairly complicated pedological phenomena and express them as functions of conceptual environmental factors and (ii) link, after an exploratory factor analysis (EFA), the conceptual factors of interest with observed variables by explicitly admitting that none of those entirely reproduces the underlying concept. The modeling framework developed at the present study is used to investigate the role of the physical properties versus the role of the chemical properties on OC content. The primary purpose was to gain insight into the relative importance of processes that influence OC content in the upper $0.5 \mathrm{~m}$ under clayey and sandy soils at the semi-arid Mediterranean regions by incorporating the potential interactions between soils properties. In conjunction with this analysis, a number of specific questions were addressed:

- Can soils properties, statistically, be rearranged in different groups?

- If there, do clayey and sandy soils have the same scattering of the groups?

- Can physical and chemical properties have independent effects on OC content?
- If there, do chemical factors have different effects on OC content than did physical factors?

- Can the suggested models be generalized?

In order to respond to these questions, SEM analysis represents an attractive solution because it helps to examine patterns of interrelationships among several latent constructs (in our case, physical and chemical properties), as well validate the suggested models. This study was conducted under all Tunisian soils during 2007 to 2009.

\section{MATERIALS AND METHODS}

In order to perform these two model; (i) first, through an exploratory factor analysis, a conceptual model of causal relationships was created between the variables of interest, at this stage the statistical software SPSS 14.0 was used; (ii) then, after underlying the latent structure, a confirmatory factor analysis (CFA) was performed, at that time the hypothesized structure was tested statistically using AMOS 4.0 software. The present framework provides more realistic estimates of the existing predictive uncertainty by taking into account both the uncertainty about the parameters and the uncertainty that remains when the parameters are known.

\section{Study area}

Tunisia $\left(32-38^{\circ} \mathrm{N} ; 7-12^{\circ} \mathrm{E}\right)$ is the northern most African country on the Mediterranean basin (Fig. 1)

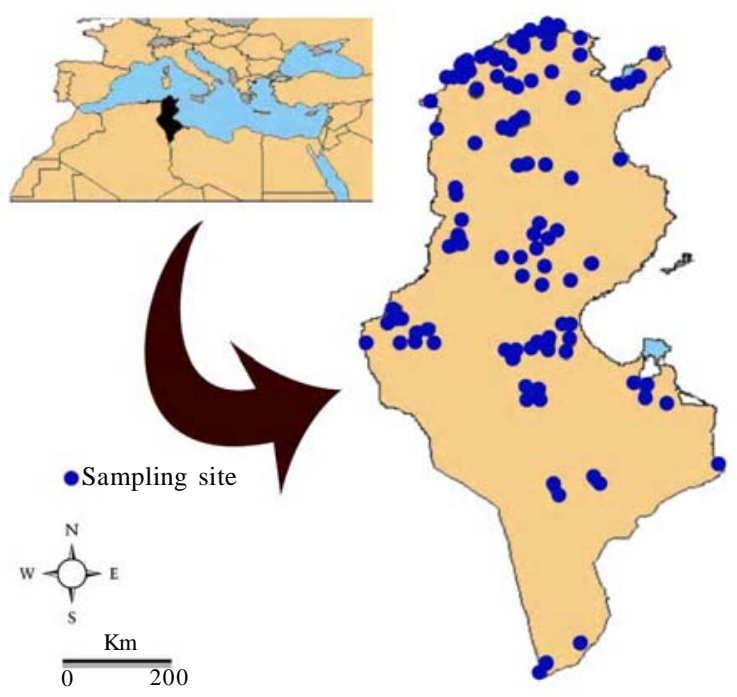

Fig. 1: Location of sampling sites in Tunisia 
and the smallest country (164.000 $\left.\mathrm{km}^{2}\right)$ among those situated at the North Africa. The Sahara desert occupies $40 \%$ of Tunisian territory, while the rest largely consists of predominantly fertile soils. The rainy season in Tunisia is typically December-March. The Mediterranean coastline $(1300 \mathrm{~km})$ is characterized by moderate temperatures, an important factor in agriculture. Tunisia contains three climatic zones: (i) northern zone, situated between Mediterranean Sea and the "Dorsale" mountain chain, the climate is Mediterranean sub-humid, mean annual precipitation in north zone ranged from 600 to $1200 \mathrm{~mm}$; (ii) Central Tunisia, situated between the "Dorsale" mountain chain and three great "Chotts" (Jerid Chott, Gharssa Chott, and Fjej Chott) represents a semi-arid zone characterized by the transition from the sub-humid Mediterranean to the arid Saharian climate, mean annual precipitation in this middle zone ranged from 200 to $600 \mathrm{~mm}$; (iii) the southern part of Tunisia limited by "Chotts" and Sahara desert, it is characterized by an increase in aridity, mean annual precipitation $<200$ $\mathrm{mm}$. Soils present an important variability, generally derived from the calcareous parent materials, and clayey texture decrease in south zone, when sandy soils commonly keep going.

\section{Databases}

This study used data from the Tunisian soils. Databases were constructed from results of analytical analysis reported for soils pits surveyed by teams of
Tunisian and IRD (ex-ORSTOM) pedologists. The data contained various information for organic matter (OM), organic carbon (OC) (was determined by the Walkley and Black (1934) method, total nitrogen (N) (by Kjeldahl digestion procedure), $\mathrm{pH}$, soil bulk density $\left(D_{b}\right)$, Clay, Silt (fine and coarse fraction), Sand (fine and coarse fraction) and calcium carbonate $\left(\mathrm{CaCO}_{3}\right)$. The list of available soil properties and methods was used for analysis are described in Table 1.

For building of two models of OC under clayey soils and sandy soils, two databases were used. The first was constructed from clayey soils, it was made of 170 soil profiles, corresponding to 450 soil horizons, the second was constructed from sandy soils it was made of 602 soil horizons, related to 285 soil profiles. For validation of models, two other databases from clayey and sandy soils were available. The primary database was composed of 157 clayey soil profiles corresponding to 397 soil horizons. The second was prepared of 185 sandy soil profiles, corresponding of 409 horizons.

\section{Development of the conceptual model}

The improvement of the conceptual model was based on what is already acquired by the earlier research, that is to say, the realization of relationships and correlations among variables has already been validated and are already known. In fact, after the works of Dokuchaev, performed last century, it is known that climate and parent material have strong effects on

Table 1: Descriptive statistics for the two soil databases: clay and sand

\begin{tabular}{|c|c|c|c|c|c|c|c|c|c|c|c|c|}
\hline & Clay \% & F-silt \% & C-silt \% & F-sand \% & C-sand \% & OC \% & $\mathrm{pH}$ & $\mathrm{OM}$ & $\mathrm{D}_{\mathrm{b}} \mathrm{Mg} \mathrm{m}^{-3}$ & $\mathrm{~N} \%$ & $\mathrm{CaCO}_{3} \%$ & $\mathrm{C} / \mathrm{N}$ \\
\hline \multicolumn{13}{|c|}{ Database of clayey soils } \\
\hline Valid case & 450 & 450 & 450 & 450 & 450 & 450 & 450 & 450 & 450 & 450 & 450 & 450 \\
\hline Med. & 45.75 & 23 & 11.2 & 11.2 & 5.25 & 1.01 & 8.10 & 1.74 & 1.52 & 0.08 & 9.50 & 10.60 \\
\hline S.D. & 12.33 & 9.87 & 7.17 & 7.16 & 6.91 & 0.92 & 0.66 & 1.63 & 0.15 & 0.18 & 17.10 & 6.03 \\
\hline Var. & 151.91 & 97.39 & 51.41 & 51.29 & 47.78 & 0.86 & 0.44 & 2.65 & 0.02 & 0.03 & 292.55 & 36.37 \\
\hline \multicolumn{13}{|c|}{ Database of sandy soils } \\
\hline Valid case & 602 & 602 & 602 & 602 & 602 & 602 & 602 & 602 & 602 & 602 & 602 & 602 \\
\hline Mean & 16.56 & 11.6 & 10.5 & 29.87 & 29.83 & 1.03 & 7.46 & 1.9 & 1.57 & 0.13 & 11.11 & 11 \\
\hline Med & 16 & 10 & 9.25 & 28 & 25 & 0.79 & 7.8 & 1.38 & 1.59 & 0.08 & 8 & 10.20 \\
\hline S.D. & 8.61 & 8.63 & 6.82 & 14.98 & 20.70 & 0.95 & 1.01 & 1.75 & 0.15 & 0.19 & 13.45 & 6.86 \\
\hline
\end{tabular}

Med.: median; SD: standard deviation; Var.: variance; Min.: minimum; Max. : maximum; $D_{\mathrm{b}}$ : soil bulk density; OM: organic matter; OC: organic carbon; $\mathrm{N}$ : total nitrogen; $\mathrm{C} / \mathrm{N}$ : ratio of carbon and nitrogen; F-Silt: fine silt; C-Silt: coarse silt; F-Sand: fine sand; C-Sand: coarse sand; $\mathrm{CaCO}_{3}$ : calcium carbonate. 
several soil properties (Gallali, 2004). Quantitative relationships between temperature and moisture on soil organic matter and clay (particles- $2 \mu \mathrm{m}$ ) contents were established several decades ago (Jenny, 1941). For the realization of conceptual models of clayey and sandy soils, some characteristics of soil variables on which based the present study were remembered briefly. The soil layers differ in $\mathrm{pH}$ and organic carbon content; the litter layer has a higher $\mathrm{pH}$ as well as organic carbon content compared to the underlying layer (Chukwuma et al., 2010). It is suggested that the higher $\mathrm{pH}$ and the higher available organic carbon in soils provide a niche for denitrification (Laverman et al., 2001). Moreover, the models predicting the effect of global warming on the decomposition of the organic carbon include the variable $\mathrm{pH}$. Leifeld et al. (2008) highlight the need to argue for a better representation of $\mathrm{pH}$ in mechanistic models particularly in regional and global up scaling exercises to substantiate predicted SOM responses to global warming. Together with the increase in soil organic carbon, an increase in total nitrogen is expected (Gudmundsson et al., 2004). The repeated tilled layer caused by different agronomic managements greatly affects the physical and chemical characteristics (Monaco et al., 2008). Agricultural management practices are known to influence soil physical properties to maintain functional capacity of soil for crop growth. Indeed, soil organic matter reduced soil bulk density and enhanced total porosity (Sultani et al., 2007). The organic carbon affects soil properties. For this, farmers have always used organic amendments to improve their physical and chemical properties. Several studies have shown that supply of exogenous organic matter can modify not only the amount of indigenous organic matter, but also the quality of bulk soil (Nardi et al., 2004; Lejon et al., 2007). Organic inputs are used to improve soil physical and chemical properties, however the corresponding changes in soil organic matter (SOM) chemical properties are not well known (Sebastia et al., 2007). The loss of organic matter is generally associated with decline in soil porosity and aggregate stability and an increase in soil strength indices like bulk density (Skidmore et al., 1986). The most observable functions of SOM include changes of soil physical properties such as bulk density, aggregate stability, porosity and water holding capacity when applied for long periods (Schjonning and Christensen, 2006). SOM is one of the most important constituents of soils; it improves the chemical and physical conditions of soils by increasing cation exchange capacity, termed buffering effect, and enhancing aggregation, aeration and water retention (Lee et al., 2009). This is how the development of the two conceptual models for clayey and sandy soils peoceeded.

\section{RESULTS AND DISCUSSION}

Exploratory Factor Analysis (EFA)

Principal component analysis (PCA) was applied, by analyzing patterns of correlations among 11 soil properties (OM, N, C/N, pH, D, Clay, F-Silt, C-Silt, FSand, C-Sand, and $\mathrm{CaCO}_{3}$ ), in order to have a more synthetic and informative description of the database. The retained components consist of weighted sum of original variables in the following mathematical model:

$\mathrm{PC}_{i 1}=\mathrm{A}_{i 1} \mathrm{X}_{1}+\mathrm{A}_{i 2} \mathrm{X}_{2}+\cdots+\mathrm{A}_{i n} \mathrm{X}_{n}$

Where:

$\mathrm{PC}=$ principal component,

$\mathrm{X}=$ the explicative variable

$\mathrm{n}=$ number of variables,

$\mathrm{i}=1,2,3, \ldots, n$

In each analysis, the Kaiser-Meyer-Olkin (KMO) test and Bartlett's test of sphericity were used to assess the appropriateness of the correlation matrices of factor analysis. The coefficients are chosen in such a way that the first component $\mathrm{PC}_{i 1}$ has the largest variance. The output of PCA is a small number of uncorrelated components accounting for a substantial proportion of the sample data variance. A range of cutoff criteria were used to determine the number of factors derived, such as eigenvalues $(\lambda)$, scree plot, percentage of variance, item communalities, and factor loadings (Dillon and Goldstein, 1984; Hair et al., 1998). Principal axis factoring extraction method with Oblimin rotation was adopted because (i) oblique rotation is best when the goal of the factor analysis is to obtain several theoretically meaningful factors and (ii) oblique rotation assumes that factors are correlated to each other, which is more justifiable and more realistic (Hair et al., 1998).

\section{The conceptual model of clayey soils}

An exploratory factor analysis (EFA) was performed, so a serie of PCAs was carried out. After the first one, the variables with low communality such as F-Silt (0.226), C-Sand (0.106), C/N (0.057), and $\mathrm{CaCO}_{3}(0.018)$ 
were deleted. The second PCA, with Direct Oblimin rotation, shows a satisfactory two-dimensional solution. Four variables expressed the component one. This factor represents the "Chemical properties and bulk density" axis, it explains $38.422 \%$ of the initial quantity of information (Table 2 ) and exhibits positive linear relationships with $\mathrm{D}_{\mathrm{b}}$ and $\mathrm{pH}$ and negative linear relationships with $\mathrm{OM}$ and $\mathrm{N}$. The second component corresponds to the "Physical properties" and explains $28.955 \%$ of the variation. This axis shows a positivecorrelation with F-Sand and C-Silt and negative correlation with Clay. Table 3 shows the matrix of correlations between organic carbon (OC) and soil properties. There are 8 variables in the matrix. The correlation coefficients show that $\mathrm{OC}$ is significantly related to all the variables. These are C-Silt and F-Sand at the 0.05 probability level, and Clay, $\mathrm{pH}, \mathrm{OM}, \mathrm{N}$ and $D_{b}$ at the 0.01 probability level. These results are corroborated by Fig. 2. It is worth noting that this analysis is precursor before SEM treatment in order to identify the structure of the proposed model (Raykov and Marcoulides, 2006; Byrne, 2009). In respect to the results obtained by the PCA and after a large literature review, a generalized conceptual model was developed as illustrated in Fig. 3. This model hypothesizes the potential interactions between the first axis (the chemical properties and bulk density factor) and OC on one hand and between the second axis (the physical factor) and $\mathrm{OC}$ on the other hand

The mathematical form of the above conceptual model is presented bellow as a structural and measure models:

The structural model: $\xi=\beta_{1} \eta_{1}+\beta_{2} \eta_{2}+D$; where:

$\xi=$ is an endogenous variable;

$\beta=$ is a matrix of regression coefficient between $\xi$ and $\eta$; $\eta=$ is an exogenous variable;

$$
\left(\begin{array}{l}
\mathrm{X}_{1} \\
\mathrm{X}_{2} \\
\mathrm{X}_{3} \\
\mathrm{X}_{4} \\
\mathrm{X}_{5} \\
\mathrm{X}_{6} \\
\mathrm{X}_{7}
\end{array}\right)=\left(\begin{array}{cc}
\lambda_{11} & 0 \\
\lambda_{12} & 0 \\
\lambda_{13} & 0 \\
0 & \lambda_{21} \\
0 & \lambda_{22} \\
0 & \lambda_{23} \\
0 & \lambda_{24}
\end{array}\right)\left(\begin{array}{l}
\eta_{1} \\
\eta_{2}
\end{array}\right)+\left(\begin{array}{l}
\varepsilon_{1} \\
\varepsilon_{2} \\
\varepsilon_{3} \\
\varepsilon_{4} \\
\varepsilon_{5} \\
\varepsilon_{6} \\
\varepsilon_{7}
\end{array}\right)
$$

Table 2: Principal components analysis of clayey soil properties after Direct Oblimin rotation

\begin{tabular}{|c|c|c|c|}
\hline \multirow{2}{*}{ Properties } & \multirow{2}{*}{ Communalities } & \multicolumn{2}{|c|}{ Pattern matrix } \\
\hline & & Chemical properties & Physical properties \\
\hline $\mathrm{pH}$ & 0.391 & 0.629 & \\
\hline $\mathrm{OM}$ & 0.769 & -0.870 & \\
\hline $\mathrm{N}$ & 0.620 & -0.793 & \\
\hline $\mathrm{D}_{\mathrm{b}}$ & 0.687 & 0.755 & \\
\hline Clay & 0.419 & & -0.625 \\
\hline C-Silt & 0.915 & & 0.963 \\
\hline F-Sand & 0.915 & & 0.963 \\
\hline Eigenvalues $(\lambda)$ & & 2.690 & 2.027 \\
\hline$\%$ Total Variance Explained & & 38.422 & 28.955 \\
\hline Cumulative variance $\%$ & & 38.422 & 67.377 \\
\hline KMO Test $\quad 0.655$ & & & \\
\hline \multicolumn{4}{|c|}{ Approx. Chi-Square: 2011.911} \\
\hline Dartlet s rest or spmencity & Signification: & 0.000 & \\
\hline
\end{tabular}

Table 3: Bivariate correlation of SOC with some clayey soil properties

\begin{tabular}{|c|c|c|c|c|c|c|c|c|}
\hline & $\mathrm{OC}$ & Clay & C-Silt & F-Sand & $\mathrm{pH}$ & $\mathrm{OM}$ & $\mathrm{N}$ & $\mathrm{D}_{\mathrm{b}}$ \\
\hline$\overline{\mathrm{OC}}$ & 1.00 & & & & & & & \\
\hline Clay & $0.143 * *$ & 1.00 & & & & & & \\
\hline C-Silt & $-0.097^{*}$ & $0.415^{* *}$ & 1.00 & & & & & \\
\hline F-Sand & $-0.098 *$ & $0.416^{* *}$ & $0.974 * *$ & 1.00 & & & & \\
\hline $\mathrm{pH}$ & $-0.366^{* *}$ & 0.056 & -0.029 & -0.028 & 1.00 & & & \\
\hline $\mathrm{OM}$ & $0.994 * *$ & $0.134 * *$ & -0.086 & -0.087 & $-0.362 * *$ & 1.00 & & \\
\hline $\mathrm{N}$ & $0.594^{* *}$ & 0.059 & -0.015 & -0.017 & $-0.341 * *$ & $0.600^{* *}$ & 1.00 & \\
\hline $\mathrm{D}_{\mathrm{b}}$ & $-0.671 * *$ & $0.292 * *$ & $0.232 * *$ & $0.234 * *$ & $0.310^{* *}$ & $-0.675 * *$ & $-0.438 * *$ & 1.00 \\
\hline
\end{tabular}

** Correlation is significant at the 0.01 level

* Correlation is significant at the 0.05 level 

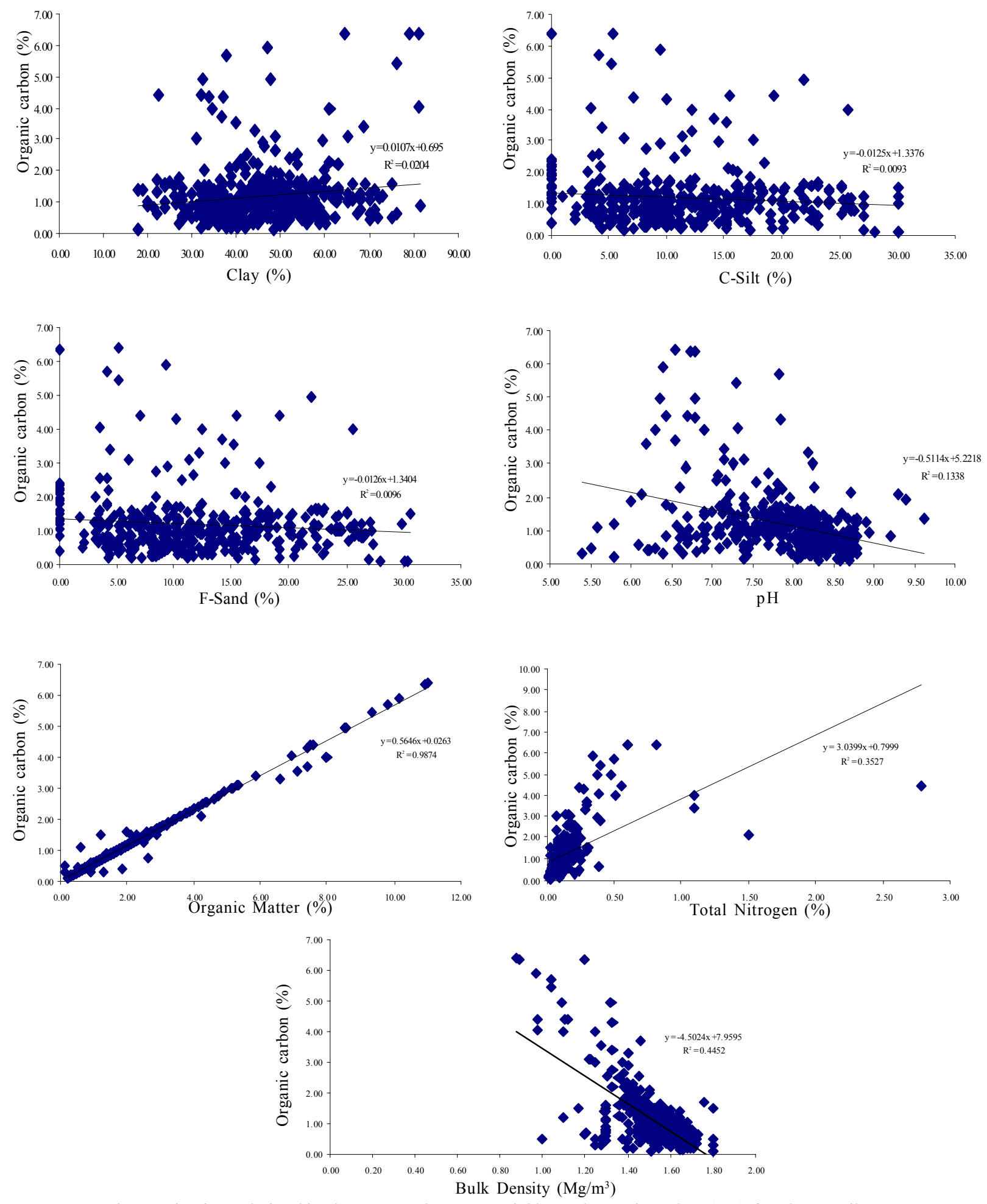

Fig. 2: Bivariate relationships between explanatory variables and organic carbon (OC) for clayey soils 


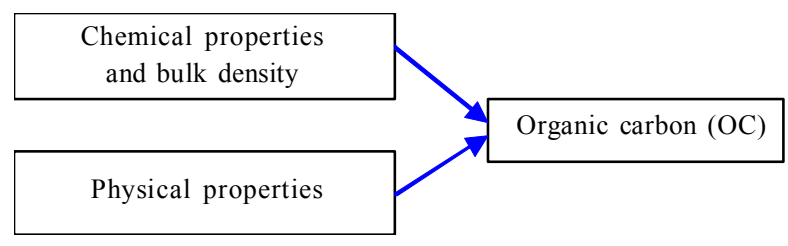

Fig. 3: The conceptual model of clayey soil

Table 4: Principal components analysis of sandy soil properties after Direct Oblimin rotation

\begin{tabular}{|c|c|c|c|}
\hline \multirow[b]{2}{*}{ Properties } & \multirow[b]{2}{*}{ Communalities } & \multicolumn{2}{|c|}{ Pattern matrix } \\
\hline & & Chemical properties & Physical properties \\
\hline $\mathrm{OM}$ & 0.577 & 0.697 & \\
\hline $\mathrm{pH}$ & 0.682 & -0.836 & \\
\hline F-sand & 0.682 & & 0.836 \\
\hline Eigenvalues $(\lambda)$ & & 1.411 & 1.006 \\
\hline$\%$ Total variance explained & & 35.265 & 25.161 \\
\hline & Approx. Chi-square: 73.226 & & \\
\hline Bartlett's test of sphericity & Signification : $\quad 0.000$ & & \\
\hline
\end{tabular}

Table 5: Bivariate correlation of SOC with some soil properties in sandy soils

\begin{tabular}{|c|c|c|c|c|c|}
\hline & $\mathrm{OC}$ & F-Silt & F-Sand & $\mathrm{OM}$ & $\mathrm{pH}$ \\
\hline $\mathrm{OC}$ & 1.00 & & & & \\
\hline F-silt & $0.143^{* *}$ & 1.00 & & & \\
\hline F-sand & $-0.104 *$ & $-0.139 * *$ & 1.00 & & \\
\hline $\mathrm{OM}$ & $0.863^{* *}$ & $0.184 * *$ & $-0.107 * *$ & 1.00 & \\
\hline $\mathrm{pH}$ & $-0.228 * *$ & $-0.090 *$ & 0.031 & $-0.239 * *$ & 1.00 \\
\hline
\end{tabular}

$* *$ Correlation is significant at the 0.01 level

* Correlation is significant at the 0.05 level

$\mathrm{D}=$ is a vector of structural errors

The measure model: $X=\Lambda \eta+\varepsilon$;

Where:

$\mathrm{X}=$ is a vector of observed variable $(\mathrm{pH}, \mathrm{OM}, \mathrm{F}-\mathrm{Sand}$, F-Silt),

$\Lambda=$ is a matrix of factor loading between $X$ and $\eta$;

$\varepsilon=$ is a vector of structural errors;

$\lambda=$ denotes the factor loadings.

The conceptual model of sandy soils

The variables were subjected to principal component analysis. This is a relatively straightforward method of transforming a given set of variables into a new set of composite variables or principal components that are orthogonal to each other. A serie of principal component analyses reduced the 11 variables to two orthogonal components having eigenvalues greater than unity (Table 4). These two factors together accounted for $60.426 \%$ of the total variance within the variables. For an improved interpretation, Direct Oblimin rotation was applied to the axes. The ultimate goal in rotation is to obtain some theoretically meaningful factors and if possible the simplest factor structure. The pattern of the variance loadings on the components, the eigenvalues, and the percentage of explained variance are shown in Table 4.

Table 5 illustrates the correlation matrix between organic carbon (OC) and soil properties. There are 5 variables in the matrix. The correlation coefficients show that $\mathrm{OC}$ is significantly related to all the variables. These are F-Sand at the 0.05 probability level, F-Silt, FSand, OM, and $\mathrm{pH}$ at the 0.01 probability level. These results are supported by those in Fig. 4.

According to the results obtained after the Exploratory Factor Analysis (EFA) and the review presented at this paper, a conceptual model was proposed, which hypothesizes the interactions between OC and the chemical properties axis as well as the physical properties axis. It is worth noting, that the model showed in Fig. 5 differs from that in Fig. 3 since the 

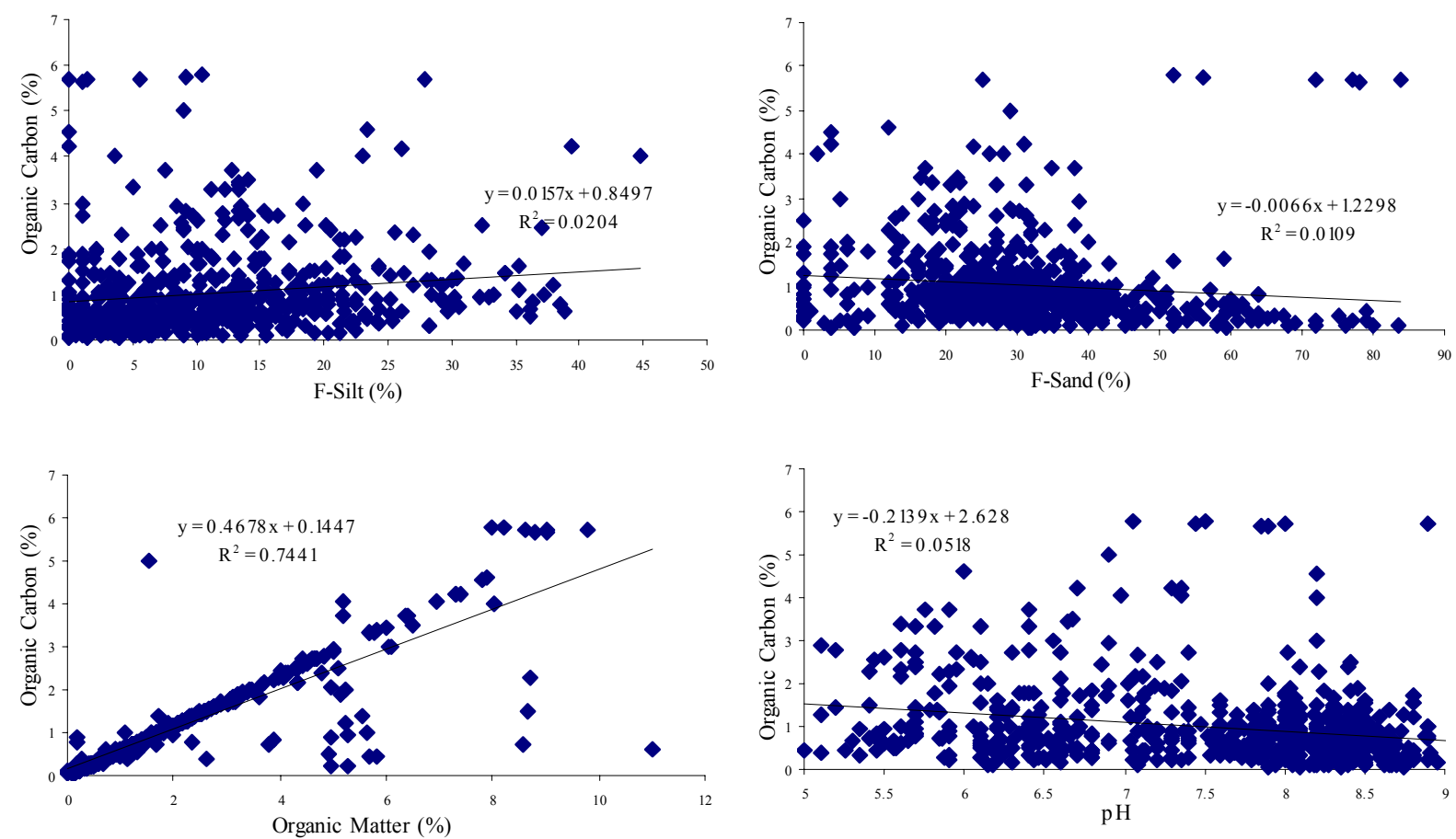

Fig. 4: Bivariate relationships between explanatory variables and organic carbon (OC) for sandy soils

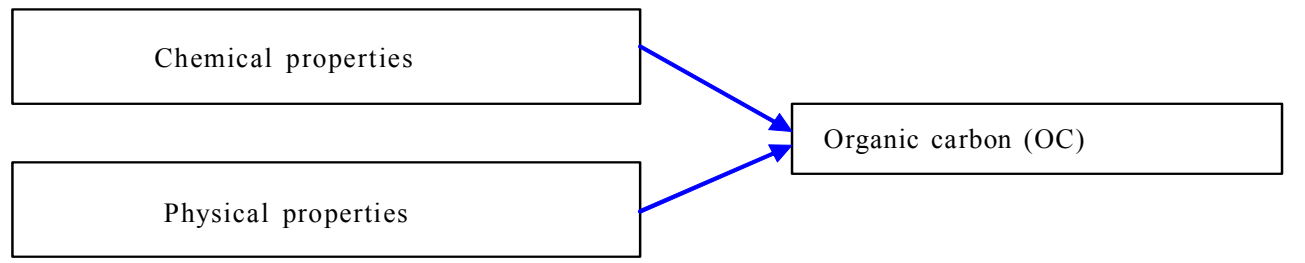

Fig. 5: The conceptual model of sandy soils

clayey and sandy soils present different characteristics at mineralogical properties and clayey richness (Wada and Aomine, 1973; Torn et al., 1997; Batjes, 1999). The second step of this study consists to test simultaneously all the variables in the conceptual models in order to assess the potential interactions between them. The structural equation modeling was used to achieve the study aims. The mathematical form of the above conceptual model is presented bellow as a structural and measure models: The structural model: $\xi={ }_{1} \eta_{1}+\beta_{2} \eta_{2}+D$;

Where:

$\xi=$ is an endogenous variable;

$\beta=$ is a matrix of regression coefficient between $\xi$ and; $\eta=$ is an exogenous variable;

$$
\left(\begin{array}{l}
\mathrm{X}_{1} \\
\mathrm{X}_{2} \\
\mathrm{X}_{3} \\
\mathrm{X}_{4}
\end{array}\right)=\left(\begin{array}{cc}
\lambda_{11} & 0 \\
\lambda_{12} & 0 \\
0 & \lambda_{21} \\
0 & \lambda_{22}
\end{array}\right)\left(\begin{array}{l}
\eta_{1} \\
\eta_{2}
\end{array}\right)+\left(\begin{array}{l}
\varepsilon_{1} \\
\varepsilon_{2} \\
\varepsilon_{3} \\
\varepsilon_{4}
\end{array}\right)
$$

$\mathrm{D}=$ is a vector of structural errors

The measure model: $X=\Lambda \eta+\varepsilon$;

Where:

$\mathrm{X}=$ is a vector of observed variable $(\mathrm{pH}, \mathrm{OM}, \mathrm{F}-\mathrm{Sand}$, F-Silt), 
$\Lambda=$ is a matrix of factor loading between $\mathrm{X}$ and $\eta$;

$\varepsilon=$ is a vector of structural errors;

$\lambda=$ denotes the factor loadings.

\section{Confirmatory Factor Analysis: Structural equation modeling (SEM)}

Structural equation modeling (SEM) is a statistical methodology that takes a confirmatory approach to the analysis of a structural theory bearing on some phenomenon. Typically, this theory represents causal processes that generate observation on multiple variables (Bentler, 1989; Bowker et al., 2005; Arhonditsis et al., 2007; Chien and Shih, 2007; Laughlina and Abellab, 2007; Chenini and Khemiri, 2009). The term structural equation modeling conveys two important aspects of the procedure: (i) that the causal processes under study are represented by a series of structural (i.e., regression) equations and (ii) that these structural relations can be modeled pictorially to enable a clearer conceptualization of the theory under study (Bollen and Long, 1993). The conceptual model can then be tested statistically in a simultaneous analysis of the entire system of variables to determine the extent to which it is consistent with the data. If the goodness of fit is adequate, the model argues for the plausibility of postulated relations among variables; if inadequate, the tenability of such relations is rejected.

In SEM, researchers are often interested in studying theoretical constructs that cannot be observed directly. These abstract phenomena are termed "latent variable" or "factors". Since latent variables are not observed directly, it follows that they cannot be measured directly. Thus, the researcher must operationally define the latent variable of interest in terms of construct believed to represent it (Bollen, 1989). As such, the unobserved variable is linked to one that is observable, thereby making its measurement possible. Assessment of the phenomenon, then constitute the direct measurement of an observed variable, although the indirect measurement of an unobserved variables.

In SEM models researchers distinguish between latent variables that are exogenous and those that are endogenous. Exogenous latent variables are synonymous with independent variables; they "cause" fluctuations in the values of other latent variables in the model. Changes in the values of exogenous variables are not explained by the model.
Rather, they are considered to be influenced by other factors external to the model. Endogenous latent variables are synonymous with dependent variables and, as such, are influenced by exogenous variables in the model, either directly or indirectly. Fluctuation in the values of endogenous variables is said to be explained by the model because all latent variables that influence them are included in the model specification.

\section{Structural equation modeling of clayey soils}

In the current study the effects of two latent variables for clayey soil, i.e., "Chemical properties and $\mathrm{D}_{\mathrm{b}}$ " and "Physical properties" were assesed. Each of these conceptual factors (latent variables) can be linked with observed variables ("what can be measured in the real world"), while it is explicitly acknowledged that none of these variables perfectly represents the underlying property (measurement errors). Specifically, it is hypothesized for clayey soil that the first latent variable "Physical properties" along with the three indicator variables; Clay, C-Silt and F-Sand.

The second latent variable is measured by four observed variables; $\mathrm{pH}, \mathrm{OM}, \mathrm{N}$ and $\mathrm{D}_{\mathrm{b}}$. The premise for the selection of these indicators was based on the findings of the principal factor analysis. The results show correlations between the measurement errors for observable indicators of the exogenous latent variables $\left(\delta_{1}\right.$ and $\delta_{5}, \delta_{1}$ and $\delta_{7}, \delta 3$ and $\left.\delta_{7}\right)$, they are well documented in the literature and strongly supported theoretically. In fact, organic matter $(\mathrm{OM})$ and mineral fraction constitute an organo-mineral complex, and generally associated with clay (Shang and Tiessen, 2001; Bayer et al., 2006; Dercova, et al., 2006). Bulk density is associated at coarse soil fraction as the sand (Jones, 1983; Bernoux et al., 1998; Benites et al., 2007).

\section{Structural equation modeling of sandy soils}

"Chemical properties" and "Physical properties" are the latent variables for sandy soil. These two latent variables are linked with observed variables. It is hypothesized that the first latent variable "Physical properties" along with the two indicator variables: F-Silt and F-Sand. The second latent variable is measured also by two observable variables: $\mathrm{pH}$ and $\mathrm{OM}$. The premise for the selection of these indicators was based on the findings of the principal factor analysis. Because OM is naturally associated with soil fraction mineral, covariances between the measurement errors were 


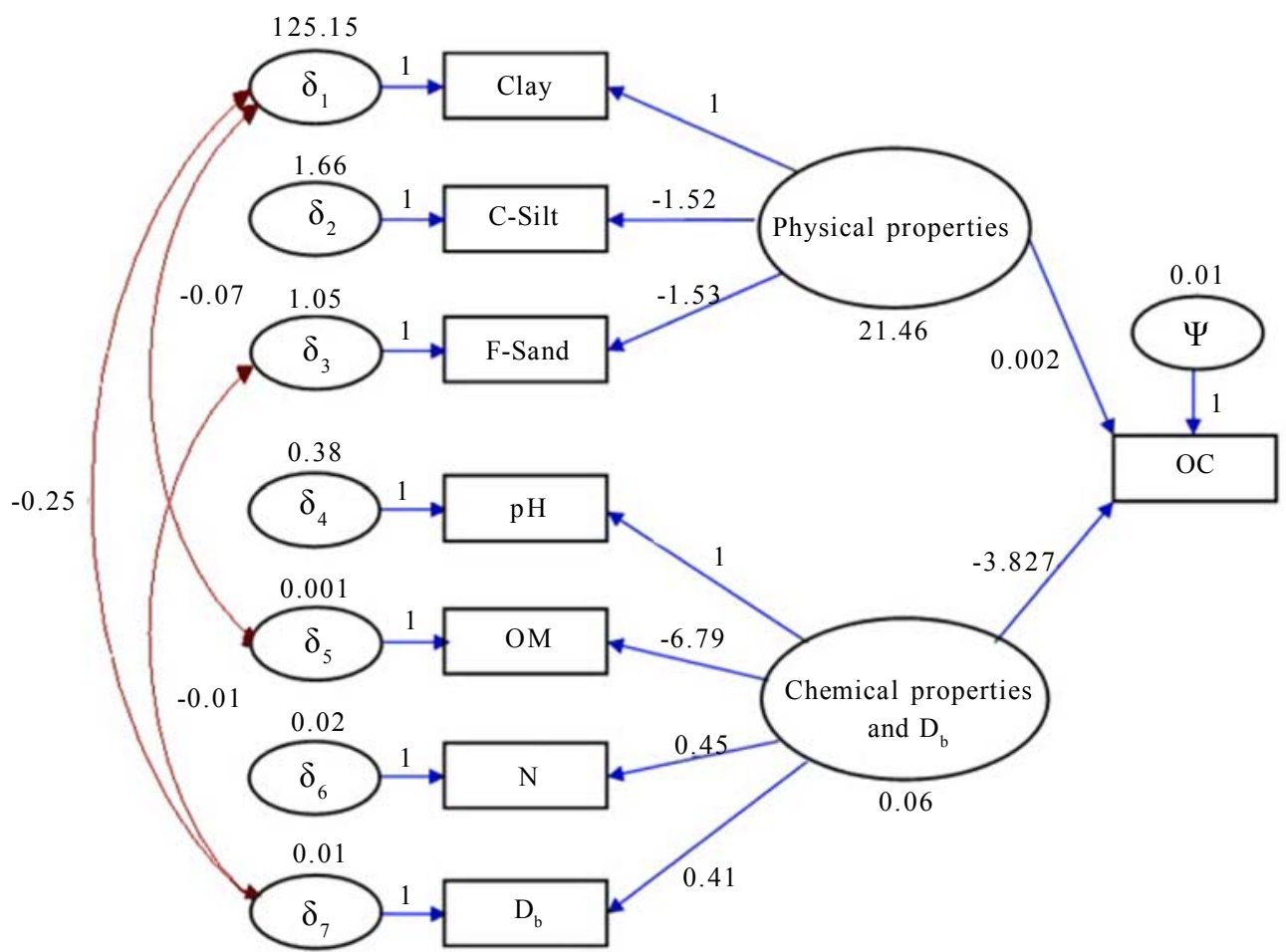

$\mathrm{x}^{2}=60.391, \mathrm{df}=16, \mathrm{GFI}=0.969, \mathrm{AGFI}=0.930, \mathrm{RMR}=1.375, \mathrm{NFI}=0.985, \mathrm{PGFI}=0.431, \mathrm{RFI}=0.974, \mathrm{IFI}=0,989, \mathrm{TLI}=0.980, \mathrm{CFI}=0.989, \mathrm{RMSEA}=0.079$

Fig. 6: The estimated parameters of the model predicting OC in clayey soils

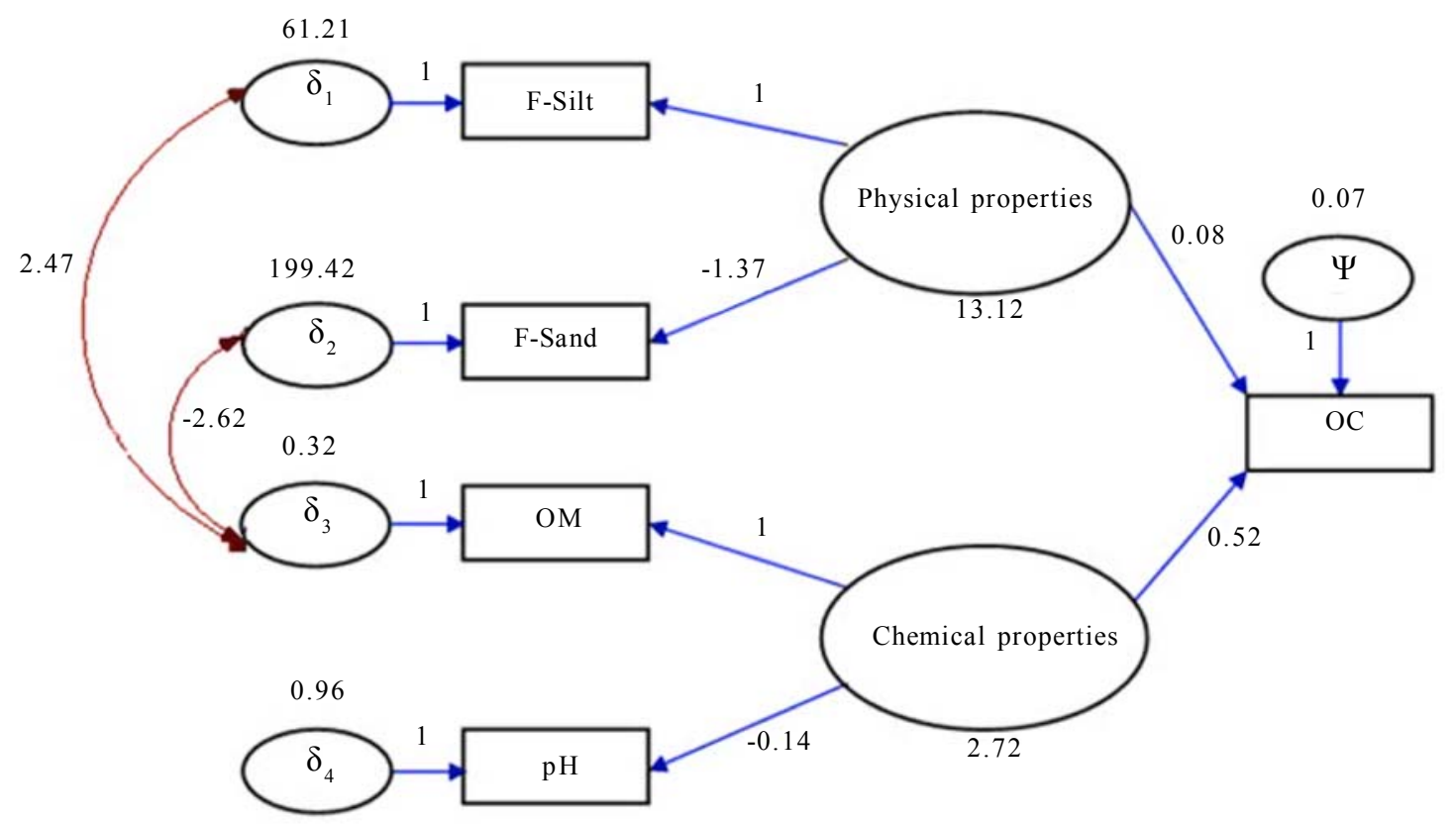

$\mathrm{x}^{2}=5.054, \mathrm{df}=2, \mathrm{GFI}=0.997, \mathrm{AGFI}=0.975, \mathrm{RMR}=0.257, \mathrm{NFI}=0.994, \mathrm{PGFI}=0.133, \mathrm{RFI}=0.972, \mathrm{IFI}=0.997, \mathrm{TLI}=0.983, \mathrm{CFI}=0.997, \mathrm{RMSEA}=0.050$

Fig. 7: The estimated parameters of the model predicting OC in sandy soils 
shown for observable indicators of the exogenous latent variables $\left(\delta_{3}\right.$ and $\delta_{1}$, and $\delta_{3}$ and $\left.\delta_{2}\right)$.

\section{SEM's results}

Standardized coefficients were used to evaluate the strength of path coefficients estimated, because the variables involved were not measured by the same measurement tool. The coefficients for the paths in models represented the strength of the direct effect of the exogenous variables on the endogenous variables. The clayey soils model has a $\chi^{2}$-value of 60.391 (degrees of freedom $(\mathrm{df})=16)$, thus $\chi^{2} / \mathrm{df}=3.77(<5)$ is a satisfactory value according to James et al., (1982). Furthermore, the sandy soils model has an acceptable $\chi^{2}(5.054) / \mathrm{df}(2)=2.52$.

All factor loadings that were tested had $t$-values greater than 1.96, so all of the path coefficients were significant (Table 6). The goodness of fit indices for the structural model that are shown in Figs. 6 and 7 indicated that the two models have a good fit of the data. The root mean square (RMR) residual represents the average value across all standardized residuals, and ranges from 0 to 1 ; in a well-fitting model this value will be small than 0.05 (Byrne, 2010). It was observed that the RMR value for the model of clay is 1.375 and 0.257 for the model of sand; It can be concluded that the models fit the data well. The adjusted goodness of fit index (AGFI) differs from the goodness of fit index (GFI) only in the fact that it adjusts for the number of degree of freedom in the specified model. They address the issue of parsimony by incorporating a penalty for the inclusion of additional parameters. The GFI and AGFI can be classified as absolute index of fit (Hu and Bentler, 1999). Although both index range from 0 to 1 , with values close to 1 being indicative of good fit, Joreskog and Sorbom (1993), theoretically it is impossible for them to be negative; Fan et al. 1999 cautioned that GFI and AGFI values can be overly influenced by sample size. Based on GFI and AGFI values $(\mathrm{GFI}=0.969$ and $\mathrm{AGFI}=0.930$ for clayey soil, and $\mathrm{GFI}=0.997$ and $\mathrm{AGFI}=0.975$ for sandy soil), it can be once again concluded that the models fit the samples data fairly well.

Parsimony goodness fit index (PGFI), was introduced by James et al. (1982) to address the issue of parsimony in SEM. The PGFI takes in to account the complexity (i.e., number of estimated parameters) of the hypothesized model in the assessment of overall model fit, as such, "to logically interdependent pieces of information" the goodness of the fit of the model (as measured by the GFI) and the parsimony of the model, are represented by a simple index (the PGFI), thereby providing a more realistic of evaluation of the model (Mulaik et al., 1989). Typically, parsimony based indexes have lower than the threshold level generally perceived as acceptable for other normed indices of fit. Thus the finding of a PGFI value of 0,431 and 0.133 for clayey model as well as sandy model, respectively, would seen to be consistent with the fit statistics.

Normed Fit Index (NFI) has been the practical criterion of choice. However, addressing evidence that the NFI has shown a tendency to under estimate fit in

Table 6: The standard regression weighs and t-values

\begin{tabular}{|c|c|c|c|c|c|c|c|c|}
\hline \multirow[b]{3}{*}{ Parameter } & \multicolumn{4}{|c|}{ Clayey soils } & \multicolumn{4}{|c|}{ Sandy soils } \\
\hline & \multicolumn{2}{|c|}{ Database 1} & \multicolumn{2}{|c|}{ Database 2} & \multicolumn{2}{|c|}{ Database 1} & \multicolumn{2}{|c|}{ Database 2} \\
\hline & $\begin{array}{c}\text { Parameter } \\
\text { value }\end{array}$ & t-value & $\begin{array}{l}\text { Parameter } \\
\text { value }\end{array}$ & t-value & $\begin{array}{c}\text { Parameter } \\
\text { value }\end{array}$ & t-value & $\begin{array}{c}\text { Parameter } \\
\text { value }\end{array}$ & t-value \\
\hline$\gamma_{1}$ & 0.002 & 2.14 & 0.002 & 2.068 & 0.08 & 2.12 & 0.11 & 2.95 \\
\hline$\gamma_{2}$ & -3.827 & -8.239 & -3.771 & -8.421 & 0.52 & 10.24 & 0.53 & 6.61 \\
\hline
\end{tabular}

Table 7: Global fit indices

\begin{tabular}{|c|c|c|c|c|}
\hline & \multicolumn{2}{|c|}{ Clayey soils } & \multicolumn{2}{|c|}{ Sandy soils } \\
\hline Goodness of fit measure & Database 1 & Database 2 & Database 1 & Database 2 \\
\hline$x^{2}$ & 60.391 & 51.946 & 5.054 & 2.339 \\
\hline AGFI & 0.930 & 0.931 & 0.975 & 0.983 \\
\hline GFI & 0.969 & 0.969 & 0.997 & 0.998 \\
\hline RMR & 1.375 & 1.308 & 0.257 & 0.283 \\
\hline RMSEA & 0.079 & 0.075 & 0.050 & 0.020 \\
\hline NFI & 0.985 & 0.985 & 0.994 & 0.995 \\
\hline TLI & 0.980 & 0.982 & 0.983 & 0.996 \\
\hline
\end{tabular}


small samples, Bentler (1990) revised the NFI to take sample size into account and proposed the Comparative Fit Index (CFI). Values for both the NFI and CFI range from 0 to 1 . Each provides a measure of complete covariation in the data, although a value larger than 0.90 was originally considered representative of a well fitting model (Bentler, 1992), a revised cut off value close to 0.95 has recently been advised (Hu and Bentler, 1999). As shown in Table 7, both the NFI of 0.994 and 0.985 for clayey model and sandy model, respectively, and CFI of 0.989 and 0.997 were consistent in suggesting that the models represented an adequate fit of the data (Figs. 6 and 7).

The relative fit index (RFI) (Bollen, 1986) represents a derivative of the NFI and the CFI, the RFI coefficient values range from 0 to 1 with values close to 0.95 indicating superior fit (Hu and Bentler, 1999). The incremental index of fit (IFI) was developed by Bollen (1989) to address the issue of parsimony and sample size which were known to be associated with the NFI. As such its computation is basically the same as the NFI, except that degree of freedom are taken into account. Thus, it is not surprising that the findings of IFI $=0.989$ for clayey model and 0.997 for sandy model were consistent with that the CFIs in reflecting a well fitting model. Finally, the Tucker Lewis index (TLI) (Tucker and Lewis, 1973) was consistent with the other index noted here, yields values ranging from 0 to $1(\mathrm{Hu}$ and Bentler, 1999). The root mean square error of approximation (RMSEA) is one of the most criteria in covariance structure modeling.

It takes into account the error of approximation and asks the question "how well would the model, with unknown but optimally chosen parameter values, fit the covariance matrix if it were available?" (Browne and Cudeck, 1989, 1993), values less than 0.08 indicate good fit. Turning to Table 7, the RMSEA values for the models are 0.050 and 0.079 for sandy model and clayey model respectively; thus, it can be concluded that the models fit the data well. Table 7 indicates that for clayey soils model the effect of Chemical properties and $D_{b}$ had a stronger effect on OC, than did Physical properties. This result is also confirmed in the second model of sandy soils.

\section{Validity check}

In order to corroborate the validity of the models, a second database was used for verification. This database was made of 157 clayey soil profiles corresponding to 397 soil horizons and 185 sandy soil profiles, corresponding of 409 horizons.

Thus, although the $\mathrm{x}^{2}$ static is significant for both samples $(p<0.01)$ it is possible to conclude that the model has been validated successfully and can be seen as appropriate for the explanation and prediction of OC under Mediterranean semi-arid climate.

\section{CONCLUSION}

The present study shows that SOC content changes with soil texture and its abundance is positively correlated with chemical and physical soil properties. After performing a principal component analysis, it was found that soils properties can be statistically rearranged in different groups (i.e. physical and chemical properties).

These two groups were different in terms of their components. Using structural equation modeling, two models were build and tested. These models provided an adequate explanation of the variance of OC content in two different soil types.

The results prove that physical and chemical properties have independent effects on OC content. In fact, the results show that in clayey soils, chemical properties and bulk density play the most important role in controlling OC content. The $\mathrm{pH}, \mathrm{OM}, \mathrm{N}$ and $\mathrm{D}_{\mathrm{b}}$ represent the key variables responsible for OC storage. In addition, in sandy soils the findings show that chemical factors (i.e. $\mathrm{OM}$ and $\mathrm{pH}$ ) are better indicators of OC content than did physical properties. Soils at semi-arid Mediterranean climate are especially threaten by erosion and desertification phenomena and the restoration of these soils needs a carbon sequestration which inhibit these two phenomena and enhance soils fertility.

The two models illustrate the main factors that affect OC in clayey and sandy soils. Finally, the two proposed models could be generalized, since the results had been obtained from the second database corroborate with those of the initial database.

\section{ACKNOWLEDGEMENTS}

This research was co-financed by AFD (Agence Française pour le Développement), the French Ministry of Foreign Affairs (MAEE), the Fond Français pour l'Environnement Mondial (FFEM), the IRD (Institut de Recherche pour le Développement) through the CORUS-2 project number 6112 "Séquestration du carbone et biodiversité dans les sols africains 
méditerranéens et leurs vulnérabilité aux changements climatiques”, the RIME-PAMPA project No. CZZ 3076 PAMPA and ARUB of Pedology Research Unit: 04/ UR/10-02.

\section{REFERENCES}

Abate, G.; Masini, J. C., (2005). Influence of pH, ionic strength and humic acid on adsorption of $\mathrm{Cd}$ (II) and $\mathrm{Pb}$ (II) onto vermiculite. Colloid. Surf. A. Physicochem. Eng. Aspects, 262 (1-3), 33-39 (7 pages).

Abdel-Ghani, N. T.; Elchaghaby, G. A., (2007). Influence of operating conditions on the removal of $\mathrm{Cu}, \mathrm{Zn}, \mathrm{Cd}$ and $\mathrm{Pb}$ ions from wastewater by adsorption. Int. J. Environ. Sci. Tech., 4 (4), 451-456 (8 pages).

Arhonditsis, G. B.; Paerl, H. W.; Valdes-Weaver, L. M.; Stow, C. A.; Steinberg, L. J.; Reckhow, K. H., (2007). Application of Bayesian structural equation modeling for examining phytoplankton dynamics in the Neuse River Estuary (North Carolina, USA). Estuarine, Coast. Shelf Sci., 72 (12), 63-80 (18 pages).

Bandyopadhyay, G.; Chattopadhyay. S., (2007). Single hidden layer artificial neural network models versus multiple linear regression model in forecasting the time series of total ozone. Int. J. Environ. Sci. Tech., 4 (1), 141-150 (10 pages).

Batjes, N. H., (1996). Total carbon and nitrogen in the soils of the world. Eur. J. Soil. Sci., 47 (2), 151-163 (31 pages).

Batjes, N. H., (1999). Management options for reducing $\mathrm{CO}_{2}$ concentrations in the atmosphere by increasing carbon sequestration in the soil. Report 410-200-031, Dutch national Research Programme on Global Air Pollution and Climate Change and Technical Paper 30, International Soil Reference and Information Centre, Wageningen.

Batjes, N. H.; Sombroek, W. G., (1997). Possibilities for carbon sequestration in tropical and subtropical soils. Glob. Chang. Biol., 3 (2), 161-173 (13 pages).

Batjes, N. H., (2006). Soil carbon stocks of Jordan and projected changes upon improved management of croplands. Geoderma, 132 (3-4), 361-371 (11 pages).

Bayer, C.; Martin-Neto, L.; Mielniczuk, J.; Dieckow, J.; Amado, T. J. C., (2006). C and N stocks and the role of molecular recalcitrance and organomineral interaction in stabilizing soil organic matter in a subtropical Acrisol managed under no-tillage. Geoderma, 133 (3-4), 258-268 (11 pages).

Bell, M. J.; Moody, P. W.; Yo, S. A.; Connoly, R. D., (1999). Using active fractions of soils organic matter as indicators of the sustainability of Ferrosol farming systems. Aust. J. Soil Res., 37 (2), 279-287 (9 pages).

Benites, V. M.; Machado, L. O. A.; Fidalgo, C. C.; Coelho, M. R.; Madari, B. E., (2007). Pedotransfer functions for estimating soil bulk density from existing soil survey reports in Brazil. Geoderma, 139 (1-2), 90-97 (8 pages).

Bentler, P. M., (1989). EQS Structural equations program manual. Los Angeles. CA: BMDP Statistical Software.

Bentler, P. M., (1990). Comparative fit indexes in structural models. Psychol. Bull., 107 (2), 238- 246 (9 pages).

Bentler, P. M., (1992). On the fit of models to covariances and methodology to the bulletin. Psychol. Bull., 112 (3), 400-404 (5 pages).
Bernoux, M.; Arrouays, D.; Cerri, C.; Volkoff, B. ; Jolivet, C., (1998). Bulk densities of Brazilian Amazon soils related to other soil properties. Soil Sci. Soc. Am. J., 62 (3), 743749 ( 7 pages).

Bernoux, M.; Carvalho, M. C. S.; Volkoff, B.; Cerri, C. C., (2002). Brazil's soil carbon stocks. Soil Sci. Soc. Am. J., 66 (3), 888-896 (9 pages).

Bicheldey, T. K.; Latushkina, E., (2010). Biogass emission prognosis at the landfills. Int. J. Environ. Sci. Tech., 7 (4), 623-628 (6 pages).

Bollen, K. A., (1986). Sample size and Bentler and Bonett's nonnormed fit index. Psychometrika, 51 (3), 375-377 (3 pages).

Bollen, K. A., (1989). Structural equation with latent variables. Wiley, New York.

Bollen, K. A.; Long, J. S., (1993). Testing structural equation models. Newbury Park, CA: sage.

Bowker, M. A.; Belnap, J.; Davidson, D. W.; Phillips, S. L., (2005). Evidence for micronutrient limitation of biological soil crusts: Importance to arid-lands restoration. Ecol. Appl., 15 (6), 1941-1951 (11 pages).

Browne, M. W.; Cudeck, R., (1989). Single sample crossvalidation indices for covariance structures. Multivariate Bihav. Res., 24 (4), 445-455 (11 pages).

Browne, M. W.; Cudeck, R., (1993). Alternative ways of assessing model fit. Sociologic. Meth. Res., 21 (2), 230-258 (29 pages).

Byrne, B. M., (2009). Structural equation modeling with AMOS basic concepts, applications and programming. $2^{\text {nd }} \mathrm{Ed}$. Routledge Taylor and Francis Group.

Caravaca, F.; Lax, A.; Albaladejo, J., (1999). Organic matter, nutrient contents and cation exchange capacity in fine fractions from semi-arid calcareous soils. Geoderma, 93 (34), 161-176 (6 pages).

Chen, D. Z.; Zhang, J. X.; Chen, J. M., (2010). Adsorption of methyl tert-butyl ether using granular activated carbon: Equilibrium and kinetic analysis. Int. J. Environ. Sci. Tech., 7 (2), 235-242 (8 pages).

Chen, Y.; Miller, J. R.; Francis, J. A.; Russell, G. L.; Aires, F., (2003). Observed and modeled relationships among Arctic climate variables. J. Geophys. Res., 108 (D24), 4799.

Chenini, I.; Khemiri, S., (2009). Evaluation of ground water quality using multiple linear regression and structural equation modeling. Int. J. Environ. Sci. Tech., 6 (3), 509-519 (11 pages).

Chien, M. K.; Shih, L. H., (2007). An empirical study of the implementation of green supply chain management practices in the electrical and electronic industry and their relation to organizational performances. Int. J. Environ. Sci. Tech., 4 (3), 383-394 (12 pages).

Christensen, B. T., (1986). Straw incorporation and soil organic matter in macro-aggregates and particle size separates. J. Soil Sci., 37 (1), 125-135 (11 pages).

Christensen, B. T., (1996). Carbon in primary and secondary organomineral complexes. In structure and organic matter storage in agricultural soils in: Cater, M. R.; Stewart, B. A., (Eds.) 97-165. CRC Press, Boca Raton.

Chukwuma, M. C.; Eshett, E. T.; Onweremadu, E. U.; Okon, M. A., (2010). Zinc availability in relation to selected soil properties in a crude oil polluted eutric tropofluvent. Int. J. Environ. Sci. Tech., 7 (2), 261-270 (10 pages). 
Dercova, K.; Sejakova, Z.; Skokanova, M.; Barancikova, G.; Makovnýkova, J., (2006). Potential use of organomineral complex (OMC) for bioremediation ofpentachlorophenol (PCP) in soil. Int. Biodeter. Biodegr., 58 (3-4), 248-253 (6 pages).

Dillon, W.; Goldstein, M., (1984). Multivariate Analysis. Methods and Application. Wiley, New York.

Dixon, J. B., (1991). Roles of clays in soils. Appl. Clay Sci., 5 (5-6), 489-503 (15 pages).

Eswaran, H.; Van den Berg, E.; Reich, P.; Kimble, J., (1995). Global soil carbon resources. in: Lal, R.; Kimble, J.; Levine, E.; Stewart, B. A. (Eds.), Soil and Global Change, 27-43. Lewis Publishers, Boca Raton.

Fan, X.; Thompson, B.; Wang, L., (1999). Effects of sample size, estimation methods, and model specification on structural equation modeling fit indexes. Struct. Equ. Model., 6 (1), 56-83 (28 Pages).

Feigl, B. J.; Sparling, G. P.; Ross, D. J.; Cerri, C. C., (1995). Soil microbial biomass in Amazonian soils: Evaluation of methods and estimates of pool sizes. Soil Biol. Biochem., 27 (11), 1467-1472 (6 pages).

Gallali, T., (2004). Clés du sol. $1^{\text {st }}$ Ed. Centre de Publication Universitaire-Tunis.

Garcia-Oliva, F.; Sanford J. R. L.; Kelly, E., (1999). Effects of slash-and-burn management on soil aggregate organic $\mathrm{C}$ and $\mathrm{N}$ in a tropical deciduous forest. Geoderma, 50 (1-2), 1-12 (12 pages).

Goyal, P.; Sharma, P.; Srivastava, S.; Srivastava, M. M., (2008). Saraca indica leaf powder for decontamination of $\mathrm{Pb}$ : Removal, recovery, adsorbent characterization and equilibrium modeling. Int. J. Environ. Sci. Tech., 5 (1), 27-34 (8 pages).

Gudmundsson, T.; Bjornsson, H.; Thorvaldsson, G., (2004). Organic carbon accumulation and $\mathrm{pH}$ changes in an Andic Gleysol under a long-term fertilizer experiment in Iceland. Catena, 56 (1-3), 213-224 (12 pages).

Guggenberger, G.; Zech, W.; Haumaier, L.; Christensen, B. T., (1995). Land-use effects on the composition of organic matter in particle-size separates of soils: II. CPMAS and solution ${ }^{13} \mathrm{C}$ NMR analysis. Eur. J. Soil. Sci., 46 (1), 147-158 (12 pages).

Hair J. F.; Anderson, R. E.; Tatham, R. L.; Black, W. C., (1998). Multivariate Data Analysis, Prentice-Hall, Upper Saddle River. (NJ: Prentice-Hall).

Hassink, J.; Whitmore, A. P., (1997). A model for the physical protection of organic matter in soils. Soil Sci. Soc. Am. J., 61, 131-139 (9 pages).

Hu, L. T.; Bentler, P. M., (1999). Cutoff criteria for indexes in covariance structure analysis: Conventional criteria versus new alternatives. Struct. Equ. Modl. Multidisci. J., 6 (1), 155 (55 Pages).

Henry, M.; Valentini, R.; Bernoux, M., (2009). Soil carbon stocks in ecoregions of Africa. Biogeosci. Discuss, 6, 797823 (27 pages).

Houghton, R. A., (1991). Tropical deforestation and atmospheric carbon-dioxide. Climatic Change, 19, 99-118 (20 pages).

Jones, C. A., (1983). Effect of soil texture on critical bulk densities for root growth. Soil Sci. Soc. Am. J. 47, 12081211 (4 pages).

James, L. R.; Mulaik, S. A.; Brett, J. M., (1982). Causal analysis: assumptions, models, and data, Beverly Hills, CA: Sage.
Jenny, H., (1941). Factors of soil formation. A system of quantitative pedology. McGraw-Hill, New York.

Joreskog, K. G.; Sorbom, D., (1993). LISREL 8: Structural equation modeling with the SIMPLIS command language. Chicago: Scientific Software International, Chicago.

Koutika, L. S.; Choné, T.; Andreux, F.; Burtin, G.; Cerri, C. C., (1999). Factors influencing carbon decomposition of topsoils from the Brazilian Amazon Basin. Biology and Fertility of Soils, 28 (4), 436-438 (3 pages).

Kay, B. D., (1998). Soil structure and organic carbon: a review. In: Soil Processes and the Carbon Cycle (Ed. By R. Lal, J. M. Kimble, R. F. Follet and B. A. Stewart), 169-197. CRC Press, Bocxa Raton.

Lal, R., (2002). Soil carbon dynamic in cropland and rangeland. Environ. Pollut., 116 (3), 353-362 (10 pages).

Lal, R., (2003). Offsetting global $\mathrm{CO}_{2}$ emissions by restoration of degraded soils and intensification of world agriculture and forestry. Land Degrad. Develop., 14 (3), 309-322 (14 pages).

Laughlina, D. C.; Abellab, S. R., (2007). Abiotic and biotic factors explain independent gradients of plant community composition in ponderosa pine forests. Ecol. Model., 205 (1-2), 231-240 (10 pages).

Laverman, A. M.; Zoomer, H. R.; Verhoef, H. A., (2001). The effect of oxygen, $\mathrm{pH}$ and organic carbon on soil-layer specific denitrifying capacity in acid coniferous forest. Soil Biol. Biochem., 33 (4-5), 683-687 (5 pages).

Lee, S. B.; Lee, C. H.; Jung, K. Y.; Park, K. D.; Lee, D.; Kim, P. J., (2009). Changes of soil organic carbon and its fractions in relation to soil physical properties in a long-term fertilized paddy. Soil Tillage Res., 104 (2), 227-232 (6 pages).

Lejon, D. P. H.; Sebastia, J.; Lamy, I.; Chaussod, R.; Ranjard, L., (2007). Relationships between soil organic status and microbial communities in agricultural soils submitted to various types of organic management. Microb. Ecol., 53 (4), 650663 (14 pages).

Leifeld, J.; Zimmermann, M.; Fuhrer, J., (2008). Simulating decomposition of labile soil organic carbon: Effects of $\mathrm{pH}$. Soil Biol. Biochem., 40 (12), 2948-2951 (4 pages).

Monaco, S; Hatch, D. J.; Sacco, D.; Bertora, C.; Grignani C., (2008). Changes in chemical and biochemical soil properties induced by 11 -yr repeated additions of different organic materials in maize-based forage systems. Soil Biol. Biochem., 40 (3), 608-615 (8 pages).

Mulaik, S. A.; James, L. R.; Vanaltine, J.; Bennett, N.; Lind, S.; Stilwell, C. D., (1989). Evaluation of goodness-of-fit indices for structural equation models. Psychol. Bull., 105 (3), 430445 (16 Pages).

Nardi, S.; Morari, F.; Berti, A.; Tosoni, M.; Giardini, L., (2004). Soil organic matter properties after 40 years of different use of organic and mineral fertilizers. Eur. J. Agron. 21 (3), 357367 (11 pages).

Okoye, A. I.; Ejikeme, P. M.; Onukwuli, O. D., (2010). Lead removal from wastewater using fluted pumpkin seed shell activated carbon: Adsorption modeling and kinetics. Int. J. Environ. Sci. Tech., 7 (4), 793-800 (8 pages).

Paustian, K.; Levine, E.; Post, W. M.; Ryzhova, I. M., (1997). The use of models to integrate information and understanding of soil $C$ at the regional scale. Geoderma, 79 (1-4), 227-260 (34 pages).

Puget, P.; Chenu, C.; Balesdent, J., (1995). Total and young organic matter distributions in aggregates of silty cultivated soils. Eur. J. Soil. Sci., 46 (3), 449-459 (11 pages). 
Quideau, S. A.; Graham, R. C.; Chadwick, O. A.; Wood, H. B., (1998). Organic carbon sequestration under chaparral and pine after four decades of soil development. Geoderma, 83 (3-4), 227-242 (16 pages).

Randall, E. W.; Mahieu, D. S.; Powlson, D. S.; Christensen, B. T., (1995). Fertilization effects on organic matter in physically fractionated soils as studied by 13C NMR: results from two long-term field experiments. Eur. J. Soil. Sci., 46 (4), 449-459 (11 pages).

Raykov, T.; Marcoulides, G. A., (2006). A first course in structural equation modeling. $2^{\text {nd }} \mathrm{Ed}$. Lawrence Erlbaum Associates Publishers, London.

Sanger, L. M.; Anderson, J. M.; Little, D.; Bolger, T., (1997). Phenolic and carbohydrate signatures of organic matter in soils developed under grass and forest plantations following changes in land use. Eur. J. Soil. Sci., 48 (2), 311-317 (7 pages).

Sebastia, J.; Labanowski, J.; Lamy, I., (2007). Changes in soil organic matter chemical properties after organic amendments. Chemosphere, 68 (7), 1245-1253 (9 pages).

Skidmore, E. L.; Layton, J. B.; Armbrust, B. V.; Hooker, M. L., (1986). Soil physical properties as influenced by cropping and residue management. Soil Sci. Soc. Am. J., 50, 415-416 (2 pages).

Scholes, M.; Andreae, M. O., (2000). Biogenic and pyrogenic emissions from Africa and their impact on the global atmosphere. Ambio, 29 (1), 23-29 (7 pages).

Shang, C.; Tiessen, H., (2001). Sequential versus parallel density fractionation of silt-sized organomineral complexes of tropical soils using metatungstate. Soil Biol. Biochem. 33 (2), 259-262 (4 pages).

Schjonning, P., Christensen, B. T., (2006). Physical and chemical properties of a sandy loam receiving animal manure, mineral fertilizer or no fertilizer for 90 years. Eur. J. Soil. Sci., 45 (3), 257-268 (12 pages).

Schlesinger, W. H., (2000). Carbon sequestration in soils: some cautions amidst optimism. Agr. Ecosyst. Environ., 82 (13), 121-127 (7 pages).

Schuman, G. E.; Janzen, H. H.; Herrick, J. E., (2002). Soil carbon dynamics and potential carbon sequestration by rangelands. Environ. Pollut., 116 (3), 391-396 (6 pages).
Sombroek, W. G.; Nachtergaele, F. O.; Hebel, A., (1993). Amounts, dynamics ans sequestering of carbon in tropical and subtropical soils. Ambio, 22 (7), 417-426 (10 pages).

Sultani, M. I., Gill, M. A., Anwar, M. M., Athar, M., (2007). Evaluation of soil physical properties as influenced by various green manuring legumes and phosphorus fertilization under rainfed conditions. Int. J. Environ. Sci. Tech., 4 (1), 109118 (10 pages)

Suthar, S.; Singh, S., (2008). Vermicomposting of domestic waste by using two epigeic earthworms (Perionyx excavatus and Perionyx sansibaricus). Int. J. Environ. Sci. Tech., 5 (1), 99-106 (8 pages).

Tucker, L. K.; Lewis, C., (1973). A reliability coefficient for maximum likelihood factor analysis. Psychometrika, 38 (1), 1-10 (10 Pages).

Torn, M. S.; Trumbmore, S. E.; Chadwick, O. A.; Vitousek, P. M.; Hendricks, D. M., (1997). Mineral control of soil organic carbon storage and turnover. Nature, 389 (6647), 170-173 (4 pages).

Wada, K.; Aomine, S., (1973). Soil development during the Quaternary. Soil Sci., 116 (3), 170-177 (8 pages).

Walkley, A.; Black, I. A., (1934). An examination of the Degtjareff method for determining soil organic matter and a proposed modification of the chromic titration method. Soil Sci., 37, 29-38 (10 pages).

Willms, C.; Lia, Z.; Allen, L.; Evans, C. V., (2004). Desorption of cesium from kaolinite and illite using alkylammonium salts. Appl. Clay Sci., 25 (3-4), 125-133 (9 pages).

Zornoza, R.; Mataix-Solera, J.; Guerrero, C.; Arcenegui, V.; Mayoral, A. M.; Morales, J.; Mataix-Beneyto, J., (2007a). Soil properties under natural forest in the Alicante Province of Spain. Geoderma, 142 (3-4), 334-341 (8 pages).

Zornoza, R.; Mataix-Solera, J.; Guerrero, C.; Victoria, A.; García-Orenes, F.; Mataix, B.; Morugán, A., (2007b). Evaluation of soil quality using multiple lineal regression based on physical, chemical and biochemical properties. Sci. Total Environ., 378 (1-2), 233-237 (5 pages).

\section{AUTHOR (S) BIOSKETCHES}

Brahim N., Ph.D. Research pedologist, U.R. Pedology 04/UR/10-02, Department of Geology, Faculty of Sciences of Tunis, el-Manar University, 2092 Tunis, Tunisia. Email: brahimnadhem@yahoo.fr

Blavet D., Ph.D. Research director in soil science, Institute for Research and Development-IRD, UMR 210 Eco\&Sols "Functional Ecology and Soil Biogeochemistry” (INRA-IRD-SupAgro), Bât. 12, 2 place Viala, 34060 Montpellier Cedex 1, France. Email: didier.blavet@ird.fr

Gallali T., Professor in soil science, U.R. Pedology 04/UR/10-02, Department of Geology, Faculty of Sciences of Tunis, el-Manar University, 2092 Tunis, Tunisia. Email: gallali.tahar@planet.tn

Bernoux M., Ph.D. Research director in soil science, Institute for Research and Development-IRD, UMR 210 Eco\&Sols "Functional Ecology and Soil Biogeochemistry” (INRA-IRD-SupAgro), Bât. 12, 2 place Viala, 34060 Montpellier Cedex 1, France. Email: martial.bernoux@ird.fr 